\title{
Cytotoxicity and genotoxicity of zingiberene on different neuron cell lines in vitro
}

\author{
Basak Togar $\cdot$ Hasan Turkez $\cdot$ Abdulgani Tatar • \\ Ahmet Hacimuftuoglu • Fatime Geyikoglu
}

Received: 19 February 2013/Accepted: 7 April 2014/Published online: 7 May 2014

(C) Springer Science+Business Media Dordrecht 2014

\begin{abstract}
The main objective of this study is to investigate the cytotoxic, genotoxic and antioxidant properties of zingiberene (ZBN) in an in vitro rat brain cell culture study. The cytotoxic effect was determined against the rat neuron and N2a neuroblastoma (N2a-NB) cell lines using the 3,(4,5-dimethylthiazol-2-yl)-2,5diphenyltetrazolium bromide assay, while the antioxidant activity was assessed using the total antioxidant capacity (TAC) and total oxidative stress (TOS) assays. The effects on DNA damage were also evaluated in this study by the single cell gel electrophoresis assay. The results indicated that ZBN has an anti-proliferative activity suppressing the proliferation of N2a-NB cells at concentrations over $50 \mathrm{mg} \mathrm{L}^{-1}$ and neuron cells at concentrations over $150 \mathrm{mg} \mathrm{L}^{-1}$. In addition, $\mathrm{ZBN}$ treatments at higher doses $\left(\leq 50 \mathrm{mg} \mathrm{L}^{-1}\right)$ led to increases of TOS
\end{abstract}

B. Togar $(\bowtie) \cdot$ F. Geyikoglu

Department of Biology, Faculty of Science, Atatürk

University, Erzurum, Turkey

e-mail: basaktogar@gmail.com

H. Turkez

Department of Molecular Biology and Genetics, Faculty of Sciences, Erzurum Technical University, Erzurum, Turkey

\section{A. Tatar}

Department of Medical Genetics, Faculty of Medical, Atatürk University, Erzurum, Turkey

\section{A. Hacimuftuoglu}

Department of Medical Pharmacology, Faculty of

Medical, Atatürk University, Erzurum, Turkey levels in N2a-NB cell cultures. However $25 \mathrm{mg} \mathrm{L}^{-1}$ of ZBN treatment caused increases of TAC levels in cultured neuron and $\mathrm{N} 2 \mathrm{a}-\mathrm{NB}$ cell cultures while $\mathrm{ZBN}$ at doses of $10-400 \mathrm{mg} \mathrm{L}^{-1}$ did not increase the number of total damage score in both cell lines. This study clearly indicates that ZBN has a significant potential to be used as a natural anticancer agent in cultured N2a-NBs.

Keywords Zingiberene - N2a neuroblastoma ·

Total oxidative stress $\cdot$ Total antioxidant capacity $\cdot$ MTT assay $\cdot$ Single cell gel electrophoresis

\section{Introduction}

Neuroblastoma (NB) stands as the most common, frequently fatal, extracranial solid tumor of early childhood, with a median age of onset of 17 months. The incidence is 10.5 per million children under 15 years of age per year, with little variation between Europe and North America, and there are 700 new cases diagnosed in the United States each year (Stiller and Parkin 1992; Brodeur 2003). NBs grow rapidly; often giving rise to metastasis (Wassberg et al. 1999). Therapy resistance to anticancer drugs represents the major limitation to the effectiveness of clinical treatment. This is a major reason for the high frequency of fatal outcome of the disease (Svensson and Larsson 2003). The incidence of cancer is a global health problem and cancer treatments do not have effective drugs as the currently available drugs are causing 
side effects in some instances. Therefore, the natural products derived from medicinal plants have gained significance in the treatment of cancer (Boopathy and Kathiresan 2010). Recently, there is a growing interest in the use of natural products for anticancer activity against cancer development (Ben Ammar et al. 2009; KilaniJaziri et al. 2009; Ben Sghaier et al. 2011). These include fatty acids, vitamins, minerals, lichens, flavonoids and terpenoids (Chaudhary et al. 2009; Iranshahi et al. 2009; Ben Sghaier et al. 2011; Ranković et al. 2011). Terpenoids are one of the most important substances of this which are naturally occurring in plants that are thought to have positive effects on human and animal health (Hamułka et al. 2012; Styrczewska et al. 2012). Sesquiterpenes, which are one of the most common terpenes, are a class of natural products with a diverse range of attractive industrial properties (Scalcinati et al. 2012). They are compounds containing three isoprene units, which is fifteen carbons and twenty-four hydrogens per molecule $\left(\mathrm{C}_{15} \mathrm{H}_{24}\right)$. There are more than 10,000 kinds of sesquiterpenes (Davis and Croteau 2000). They have long been investigated for biological activities; anticarcinogenic (Afoulous et al. 2013), antimicrobial (Wang et al. 2013), antifungal (Kundu et al. 2013), anti-inflammatory (Wang et al. 2013), and, more recently, antioxidant (Abolaji et al. 2013) activities.

Zingiberene (ZBN) is a sesquiterpene hydrocarbon present as the main active component of the essential oils in ginger rhizomes (Jeena et al. 2011; Antonious and Kochhar 2003). ZBN has been used in the odors and cosmetics industry for a long time (Denyer et al. 1994). Furthermore, previous reports indicated that ZBN has antifertility, antiviral, antiulcer and anticancer effects (Denyer et al. 1994; Millar 1998; Bou et al. 2013).

To our best knowledge, there has been no report of cytotoxic and genotoxic investigation for ZBN in rat neuron and N2a-NB cell cultures so far. Therefore, we aimed to assess the cytotoxic (by MTT assay), oxidative (by TAC and TOS levels) and genotoxic (by SCGE assay) effects of ZBN in cultured rat neuron and $\mathrm{N} 2 \mathrm{a}-\mathrm{NB}$ cells for the first time.

\section{Materials and methods}

Test compound and chemicals

Zingiberene (Cas: 495-60-3, $\mathrm{C}_{15} \mathrm{H}_{24}$, (5R)-2-methyl-5[(2S)-6-methylhept-5-en-2yl] cyclohexa-1,3-diene

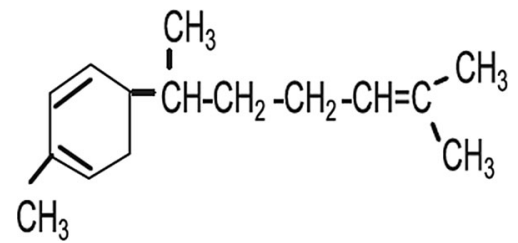

Fig. 1 Chemical structures of zingiberene

(Fig. 1; Antonious and Kochhar 2003) was purchased by Guide Chem ${ }^{\circledR}$ (Beijing, China). Dulbecco modified Eagles medium (DMEM), Hank's balanced salt solution (HBSS), neurobasal medium (NBM), sodium phosphate $\left(\mathrm{NaH}_{2} \mathrm{PO}_{4}\right)$, monobasic potassium phosphate $\left(\mathrm{KH}_{2} \mathrm{PO}_{4}\right)$, ethylenediaminetetraacetic acid (EDTA), phosphate buffer solution (PBS), dimethylsulfoxide (DMSO), Triton-X-100, Tris, low melting point agarose, normal melting point agarose were purchased from Sigma ${ }^{\circledR}$ Co. (St. Louis, MO, USA). Hydrogen peroxide was purchased from Merck ${ }^{\circledR}$ (Darmstadt, Germany). Fetal calf serum (FCS) and trypsin-EDTA were purchased from Biological Industries $^{\circledR}$ (Beit-Haemek, Israel). All other chemicals were of analytical grade.

N2a neuroblastoma cell cultures

We employed the N2a-NB cell line widely used as a model for brain cancer. The rat brain NB cell line N2a was obtained from the Turkey FMD Institute (Ankara, Turkey). Prior to the experiments, the cells were thawed and grown in tissue culture flasks as a monolayer in DMEM supplemented with $1 \%$ glutamine, $0.5 \%$ penicillin/streptomycin (Pan Biotech ${ }^{\circledR}$, Aidenbach, Germany) and $10 \%$ fetal bovine serum at $37{ }^{\circ} \mathrm{C}$ in a humidified $(95 \%)$ incubator with $\mathrm{CO}_{2}$ $(5 \%)$. The cultured cells were trypsinised with trypsin/EDTA for a maximum of $5 \mathrm{~min}$ and seeded with a subcultivation ratio of 1:3-1:8.

Healthy neuron cell cultures

This study was conducted at the Medical Experimental Research Centres at the Ataturk University (Erzurum, Turkey). The Ethical Committee of Ataturk University approved the study protocol (B.30.2.ATA.0.23.85-73). Primary rat cerebral cortex neuron cultures were prepared using rat foetuses as described previously (Ban et al. 2006). Briefly, a total of nine new-born Sprague-Dawley rats were used in the study. The rats 
were decapitated by making a cervical fracture in the cervical midline and the cerebral cortex was dissected and removed. The cerebral cortex was placed into $5 \mathrm{~mL}$ of HBSS, which had already been placed in a sterile petri dish and macromerotomy was performed with two lancets. The cerebral cortices were dissociated with HBSS, were pulled into a syringe and treated at $37{ }^{\circ} \mathrm{C}$ for $25-30 \mathrm{~min}$ in $5 \mathrm{~mL}$ HBSS plus $2 \mathrm{~mL}$ TrypsinEDTA (0.25\% trypsin-0.02\% EDTA) and chemical decomposition was achieved. Eight $\mu \mathrm{L}$ of DNase type 1 (St. Louis, MO, USA) was added to this solution and treated for 1-2 min, and centrifuged at $800 \mathrm{rpm}$ for $3 \mathrm{~min}$. After having thrown away the supernatant, $31.5 \mathrm{~mL}$ of NBM and $3.5 \mathrm{~mL}$ FCS were added to the residue. The single cells which were obtained after physical and chemical decomposition were divided into $3.5 \mathrm{~mL}$ samples in each of 10 flasks coated with poly-Dlysine formerly dissolved in PBS. The flasks were left in the incubator including $5 \% \mathrm{CO}_{2}$ at $37{ }^{\circ} \mathrm{C}$. The single cell which was obtained after physical and chemical decomposition was divided into $3.5 \mathrm{~mL}$ samples in each of 10 flasks coated with poly-D-lysine formerly dissolved in PBS. The flasks were left in the incubator including $5 \% \mathrm{CO}_{2}$ at $37{ }^{\circ} \mathrm{C}$. The neuron cell cultures were used in experiments after 8 days in vitro.

\section{Treatments}

ZBN was dissolved in hexane and hexane was evaporated to dryness at ambient temperature (final concentration of hexan $<0.2 \%$ ). The concentrations were selected according to the works of Wang et al. (2009). In this study, ZBN was used in eight distinct doses at concentrations of 10, 25, 50, 75, 100, 150, 200 and $400 \mathrm{mg} \mathrm{L}^{-1}$.

\section{Cytotoxicity assay}

Viability of cells was assessed by measuring the formation of formazan from MTT spectrophotometrically via a commercial kit (Cayman Chemical ${ }^{\circledR}$, Ann Arbor, MI, USA). Rat neuron and N2a-NB cells were seeded in each 48-well plates. After incubation with compounds for $24 \mathrm{~h}$, MTT solution (final amount $10 \mu \mathrm{L}$ ) was added to each well and re-incubated for $4 \mathrm{~h}$ at $37^{\circ} \mathrm{C}$. After washing, the blue formazan was extracted from the cells with isopropanol/formic acid (95:5) and was photometrically determined at $560 \mathrm{~nm}$ (Lewerenz et al. 2003; Turkez et al. 2012b; Aydin et al. 2014).
Biochemical assay

The automated total antioxidant capacity (TAC) and total oxidant status (TOS) assays were carried out in the culture medium by a commercially available kit (Rel Assay Diagnostics ${ }^{\circledR}$, Gaziantep, Turkey) on rat neurons and N2a-NB cell cultures for $24 \mathrm{~h}$ (Erel 2004, 2005; Turkez et al. 2012a, c).

\section{Genotoxicity assay}

In this study, the DNA damage evaluation was performed by Comet (SCGE) assay (Singh et al. 1988). After the application of coverslips, the slides were allowed to gel at $4{ }^{\circ} \mathrm{C}$ for $30-60 \mathrm{~min}$. The slides were immersed in freshly prepared cold lysing solution (2.5 M NaCl, $100 \mathrm{mM}$ EDTA, $10 \mathrm{mM}$ Tris $\mathrm{pH} 10$ in which $10 \%$ DMSO and $1 \%$ Triton X-100 were added) and refrigerated overnight followed by alkali treatment (300 mM NaOH, $1 \mathrm{mM}$ EDTA pH >13), electrophoresis $(25 \mathrm{~V}, 300 \mathrm{~mA})$ and neutralization $(0.4 \mathrm{M}$ Tris, $\mathrm{pH}$ 7.5). The dried slides were then stained using Ethidium bromide ( $50 \mu \mathrm{L}^{-1}$ of $20 \mu \mathrm{g} \mathrm{mL}^{-1}$ ), (SigmaAldrich $^{\circledR}$, St Louis, MO, USA) after appropriate fixing. The whole procedure was carried out in dim light to minimize artefacts. DNA damage analysis was performed at a magnification of $100 \times$ using a fluorescence microscope (Nikon Eclips E6600, Japan) after coding the slides by one observer (Togar B). A total of 100 cells were screened per slide. A total damage score for each slide was derived by multiplying the number of cells assigned to each grade of damage by the numeric value of the grade and summing over all grades (giving a maximum possible score of 400 , corresponding to 100 cells at grade 4; Ozkan et al. 2009).

\section{Results}

The MTT assay was used to quantify cell viability in response to ZBN. The results of MTT analysis showed that ZBN significantly suppressed the proliferation of $\mathrm{N} 2 \mathrm{a}-\mathrm{NB}$ cells, at higher concentrations than $50 \mathrm{mg} \mathrm{L}^{-1}$ (100, 150, 200 and $400 \mathrm{mg} \mathrm{L}^{-1}$ ) compared to control value. However, ZBN treatments showed anti-proliferative activity on healthy neuron cells at concentrations over $150 \mathrm{mg} \mathrm{L}^{-1}$ (200 and $400 \mathrm{mg} \mathrm{L}^{-1}$; Fig. 2).

Table 1 presents the comparison of oxidant-antioxidant profile of ZBN on cultured primary rat neurons and 
Fig. 2 Cytotoxic effect of zingiberene (ZBN) on cultured rat neurons and N2a-NB cells. The results are given as the mean $\pm \mathrm{SD}$ from six independent experiments. Compared with control, ${ }^{*} p<0.05$

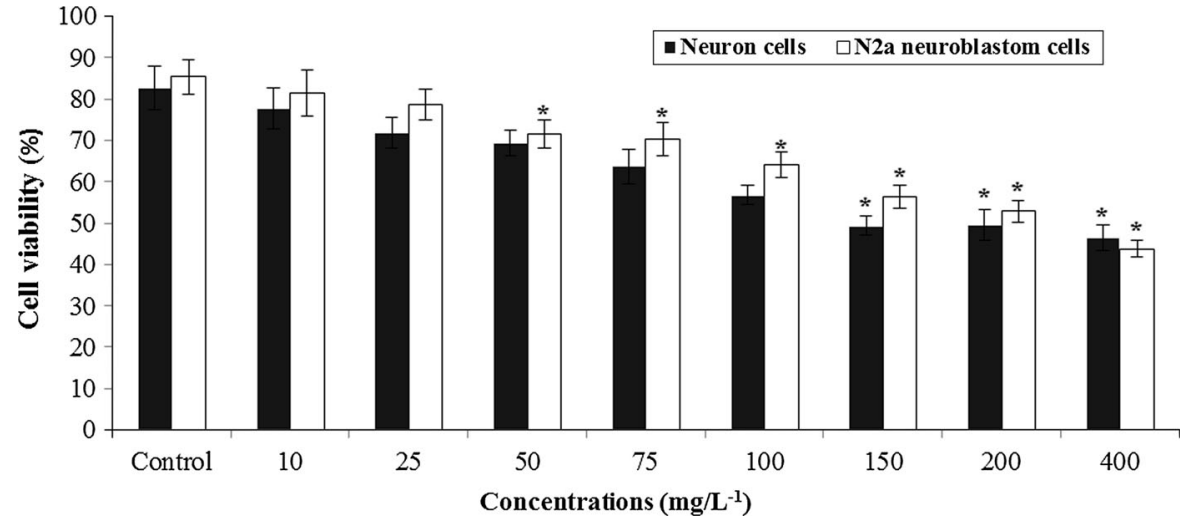

Table 1 In vitro TAC and TOS levels in cultured neuron and N2a-NB cells maintained $24 \mathrm{~h}$ in the presence of zingiberene (ZBN)

\begin{tabular}{|c|c|c|c|c|}
\hline \multirow{2}{*}{$\begin{array}{l}\text { Cells } \\
\text { Concentrations } \\
\left(\mathrm{mg} \mathrm{L}^{-1}\right)\end{array}$} & \multicolumn{2}{|c|}{ Healthy neuron } & \multicolumn{2}{|c|}{ N2a Neuroblastoma } \\
\hline & $\begin{array}{l}\text { TAC (mmol Trolox } \\
\left.\text { Equiv. } \mathrm{L}^{-1}\right)\end{array}$ & $\begin{array}{l}\text { TOS }\left(\mathrm{mmol} \mathrm{H}_{2} \mathrm{O}_{2}\right. \\
\left.\text { Equiv. } \mathrm{L}^{-1}\right)\end{array}$ & $\begin{array}{l}\text { TAC }(\text { mmol Trolox } \\
\left.\text { Equiv. } \mathrm{L}^{-1}\right)\end{array}$ & $\begin{array}{l}\text { TOS }\left(\mathrm{mmol}_{2} \mathrm{O}_{2}\right. \\
\left.\text { Equiv. } \mathrm{L}^{-1}\right)\end{array}$ \\
\hline Control & $28.6 \pm 3.0$ & $1.7 \pm 0.1$ & $6.1 \pm 0.5$ & $2.3 \pm 0.2$ \\
\hline 10 & $28.9 \pm 2.9$ & $1.6 \pm 0.2$ & $6.8 \pm 0.5$ & $2.3 \pm 0.1$ \\
\hline 25 & $31.6 \pm 2.3^{*}$ & $1.7 \pm 0.1$ & $7.3 \pm 0.6^{*}$ & $2.4 \pm 0.3$ \\
\hline 50 & $29.0 \pm 4.0$ & $1.8 \pm 0.2$ & $6.8 \pm 0.8$ & $2.6 \pm 0.2^{*}$ \\
\hline 75 & $28.7 \pm 2.7$ & $1.8 \pm 0.3$ & $6.4 \pm 0.7$ & $2.8 \pm 0.3^{*}$ \\
\hline 100 & $28.3 \pm 3.1$ & $2.0 \pm 0.2$ & $5.3 \pm 0.7^{*}$ & $2.7 \pm 0.2^{*}$ \\
\hline 150 & $23.5 \pm 2.8^{*}$ & $2.4 \pm 0.1^{*}$ & $4.2 \pm 0.6^{*}$ & $2.9 \pm 0.1^{*}$ \\
\hline 200 & $22.3 \pm 2.6^{*}$ & $2.5 \pm 0.1^{*}$ & $3.7 \pm 0.4^{*}$ & $2.9 \pm 0.1^{*}$ \\
\hline 400 & $22.1 \pm 2.3^{*}$ & $2.5 \pm 0.1^{*}$ & $3.9 \pm 0.5^{*}$ & $2.9 \pm 0.1^{*}$ \\
\hline
\end{tabular}

TAC total antioxidant capacity; TOS total oxidant status

The results are given as the means \pm SD from six independent experiments. Compared with control, ${ }^{*} p<0.05$

N2a-NB cell cultures. As seen from the Table 1, 150, 200 and $400 \mathrm{mg} \mathrm{L}^{-1}$ concentrations of ZBN did not lead to any alterations in TAC levels, while $25 \mathrm{mg} \mathrm{L}^{-1}$ of ZBN treatments caused significant increases of TAC levels in cultured primary rat neuron cells as compared to control value. Also, ZBN caused statistically important $(p<0.05)$ increases in TOS levels at concentrations higher than $100 \mathrm{mg} \mathrm{L}^{-1}$ in comparison with control values on rat neuron cell line. Likewise, ZBN (at $25 \mathrm{mg} \mathrm{L}^{-1}$ ) did not cause any alterations in TAC levels on rat N2a-NB cell cultures. However, 100, 150, 200 and $400 \mathrm{mg} \mathrm{L}^{-1}$ of ZBN applications caused significant decreases of TAC levels when compared to controls. On the other hand, the TOS levels increased at 50, 100, 150, 200 , and $400 \mathrm{mg} \mathrm{L}^{-1}$ concentrations of $\mathrm{ZBN}$ in cultured N2a-NB cells, respectively.
Comet assay was performed on healthy neuron and $\mathrm{N} 2 \mathrm{a}-\mathrm{NB}$ cell lines to measure the genotoxicity of ZBN. As shown in Fig. 3, the mean values of the total scores of cells showing DNA damage were not found to be significantly different from the control values in both cells. Besides, the neuron and N2a-NB cultures were found to be sterile at higher concentration of ZBN (400 mg L ${ }^{-1}$ ).

\section{Discussion}

In the present study, we evaluated the cytotoxic effect of $\mathrm{ZBN}$ on rat neuron and N2a-NB cells via 3-(4.5dimethylthiazol-2-yl)-2.5-diphenyl tetrazolium bromide (MTT) assay, for the first time. In fact, the MTT 
Fig. 3 Effect of varying concentrations of zingiberene (ZBN) on induction of DNA damage in vitro for $24 \mathrm{~h}$

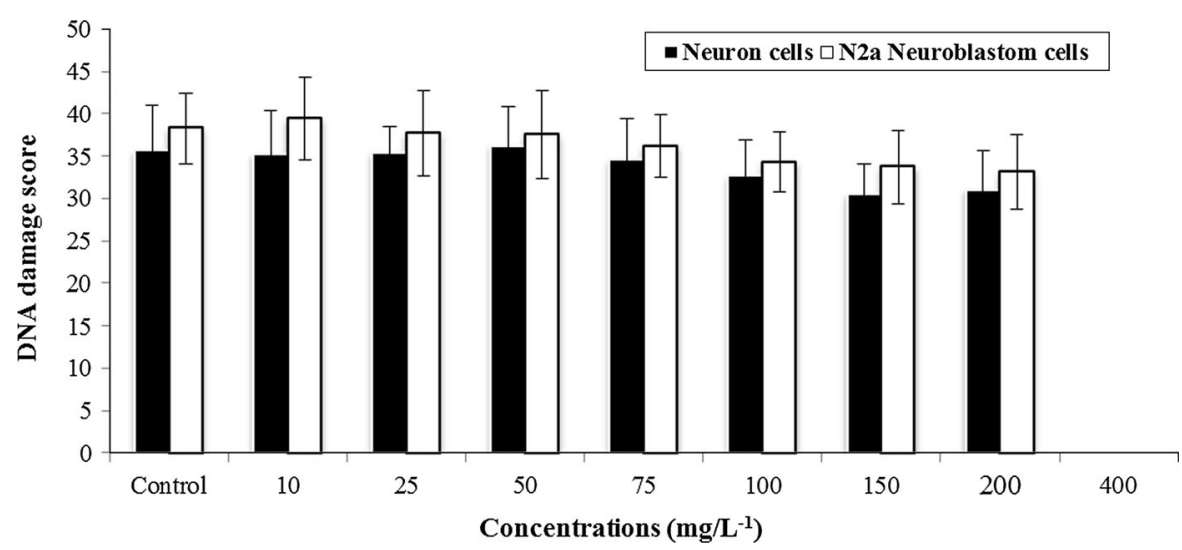

colorimetric assay is an established method for determining viable cell number in proliferation and cytotoxicity studies. Since the MTT assay is rapid, convenient, and economical, it has become a very popular technique for quantification of viable cells in culture (Sylvester 2011). We found that $Z B N$ at $150 \mathrm{mg} \mathrm{L}^{-1}$ significantly reduced the cell viability of cultured primary rat neurons, while $\mathrm{ZBN}$ at concentrations above than $50 \mathrm{mg} \mathrm{L}^{-1}$ significantly reduced the cell viability of N2a-NB cells. Our findings were in line with previous reports. Similar to our findings, it was reported that the purified $\alpha-Z B N$ from the essential oil from leaves of Casearia sylvestris showed a cytotoxic activity against HeLa, U-87, Siha and HL60 cell lines (Bou et al. 2013). Our results are also in agreement with previous studies which have reported that parthenolide demonstrated strong cytotoxicity towards human lung carcinoma (A549), human medulloblastoma (TE671), human colon adenocarcinoma (HT-29) cells in the MTT in vitro assay (Parada-Turska et al. 2007). Also, Wang et al. (2001) revealed that artesunate showed evident cytotoxicity to human hepatocarcinoma SMMC-7721 cells. In addition, Taha et al. (2010) demonstrated that zerumbone (a monosesquiterpene found in the subtropical ginger), showed a strong cytotoxic effect in rat liver (DEN/AAF-induced) cancer cell lines. These results suggest a dose-dependent cytotoxic and antiproliferative effect of ZBN on neuron and N2a-NB cell cultures.

Many studies reported that while the in vitro or in vivo antioxidant capacity of several sesquiterpenes exists, antioxidant capacity of ZBN did not see in different cell types. For assessing the antioxidant/ oxidant effects of ZBN, total antioxidant capacity (TAC) and total oxidant status (TOS) assays were performed. Actually, rapid and reliable automated colorimetric assay for TAC and TOS are frequently used to determine the impact of increasing increased oxidative damage with altered antioxidative status (Kusano and Ferrari 2008). Our results reported that a concentration of ZBN of $25 \mathrm{mg} \mathrm{L}^{-1}$ caused an increase of TAC level in neuron and N2a-NB cell cultures. On the other hand our results showed that ZBN (higher than $100 \mathrm{mg} \mathrm{L}^{-1}$ ) caused increases in TOS levels in healthy neurons. And high concentrations of ZBN (higher than $50 \mathrm{mg} \mathrm{L}^{-1}$ ) caused significant increases in TOS levels in N2a-NB cells. The exact mechanisms of the cytotoxic action of ZBN are not known, but oxidative stress is thought to be the main responsible mechanism in its cellular toxicity. Previous studies reported that different mechanisms have been linked to cytotoxicity of plant products, (I) including proteasome inhibition, (II) topoisomerase inhibition, (III) inhibition of fatty acid synthesis, (IV) accumulation of p53, (V) induction of cell cycle arrest, (VI) inhibition of phosphatidyl-inositol 3-kinase or (VII) enhanced expression of c-fos and c-myc including oxidative stress (Constantinou et al. 1995; Lepley et al. 1996; Plaumann et al. 1996; Agullo et al. 1997; Chen et al. 1998, 2005; Kazi et al. 2004; Brusselmans et al. 2005).

In this study, we investigated the genotoxic potential of ZBN by using the comet assay. The comet assay is a rapid, sensitive and relatively simple assay for measurements of DNA damage (Singh et al. 1988). As far as we know, the genotoxicity of ZBN has not been investigated on cultured rat neurons and N2a-NB cells. Also, there are no studies on the genotoxic effect of zingiberene on any cell line. Our findings also indicate that $\mathrm{ZBN}$ is neither genotoxic nor mutagenic on neurons and N2a-NB cells using the comet assay since the observed mean values of the total scores of 
cells showing DNA damage was not found significantly different from the control values. To the best of our knowledge, there is no information on the genotoxic effect of ZBN on cell culture systems. Therefore, we have discussed its genotoxicity potential as compared with other sesquiterpenes. Similar to our finding it was suggested that beta-caryophyllene by itself did not produce any cytotoxic and genotoxic effect, as shown by the value of the nuclear division index (NDI) and the frequency of micronuclei (MN) in human lymphocytes cultures (Di Sotto et al. 2010). Likewise, Anter et al. (2011) reported that apigenin, bisabolol, and protocatechuic acid did not exhibit any genotoxic effect in DNA fragmentation assay. Additionally, it was found that gossypol significantly depressed the mitotic index but did not alter chromosome numbers or increase the frequency of chromosomal structural abnormalities. Moreover, Al-Zubairi et al. (2010) demonstrated that zerumbone is a cytotoxic but not a clastogenic substance in human peripheral blood lymphocytes. On the other hand, Mishima et al. (2005) reported that baccharin and drupanin induced a significant genotoxic effect on the tumor cells sarcoma S-180 in comparison with normal splenocytes using comet assay. In addition, it was demonstrated that deoxynivalenol an epoxy-sesquiterpenoid, was able to induce lymphocyte DNA damage in chickens (Awad et al. 2012). These divergent results suggest the relevance of the chemical structure in the biological effect of sesquiterpenes and indicate as well the importance of using various test models to reach a valid conclusion.

In conclusion our in vitro cytotoxic studies suggest that high concentrations of ZBN used in the present investigation may be cytotoxic. This study concludes that ZBN has weak anticancer activity in vitro. However, further studies are needed to further elucidate the mechanisms of ZBN to improve our understanding of their anticancer effect using different in vivo and in vitro cancer models.

Acknowledgments This work was supported by the Scientific \& Technological Research Council of Turkey (TÜBİTAK, Project Number: 210T142).

\section{References}

Abolaji AO, Eteng MU, Omonua O, Adenrele Y (2013) Influence of coadministration of artemether and lumefantrine on selected plasma biochemical and erythrocyte oxidative stress indices in female Wistar rats. Hum Exp Toxicol 32:206-215

Afoulous S, Ferhout H, Raoelison EG, Valentin A, Moukarzel B, Couderc F, Bouajila J (2013) Chemical composition and anticancer, antiinflammatory, antioxidant and antimalarial activities of leaves essential oil of Cedrelopsis grevei. Food Chem Toxicol 56:352-362

Agullo G, Gamet-Payrastre L, Manenti S, Viala C, Remesy C, Chap H, Payrastre B (1997) Relationship between flavonoid structure and inhibition of phosphatidylinositol 3-kinase: a comparison with tyrosine kinase and protein kinase c inhibition. Biochem Pharmacol 53:1649-1657

Al-Zubairi AS, Abdul AB, Syam MM (2010) Evaluation of the genotoxicity of zerumbone in cultured human peripheral blood lymphocytes. Toxicol In Vitro 24:707-712

Anter J, Romero-Jiménez M, Fernández-Bedmar Z, VillatoroPulido M, Analla M, Alonso-Moraga A, Muñoz-Serrano A (2011) Antigenotoxicity, cytotoxicity, and apoptosis induction by apigenin, bisabolol, and protocatechuic acid. J Med Food 14:276-283

Antonious GF, Kochhar TS (2003) Zingiberene and curcumene in wild tomato. J Environ Sci Health B 38:489-500

Awad WA, Ghareeb K, Dadak A, Gille L, Staniek K, Hess M, Böhm J (2012) Genotoxic effects of deoxynivalenol in broiler chickens fed low-protein feeds. Poult Sci 91:550-555

Aydin E, Turkez H, Keles MS (2014) The effect of carvacrol on healthy neurons and $\mathrm{N} 2 \mathrm{a}$ cancer cells: some biochemical, anticancerogenicity and genotoxicity studies. Cytotechnology 66:149-157

Ban JY, Jeon SY, Nguyen TT, Bae K, Song KS, Seong YH (2006) Neuroprotective effect of oxyresveratrol from smilacis chinae rhizome on amyloid $\beta$ protein (25-35)induced neurotoxicity in cultured rat cortical neurons. Biol Pharm Bull 29:2419-2424

Ben Ammar R, Bhouri W, Ben Sghaier M, Boubaker J, Skandrani I, Neffati A, Chekir-Ghedira L, Ghedira K (2009) Antioxidant and free radical-scavenging properties of three flavonoids isolated from the leaves of Rhamnus alaternus L. (Rhamnaceae): a structure-activity relationship study. Food Chem 116:258-264

Ben Sgha1er M, Skandrani I, Nasr N, Franca MG, ChekirGhedira L, Ghedira K (2011) Flavonoids and sesquiterpenes from Tecurium ramosissimum Promote antiproliferation of human cancer cells and enhance antioxidant activity: a structure-activity relationship study. Environ Toxicol Pharmacol 32:336-348

Boopathy NS, Kathiresan K (2010) Anticancer drugs from marine flora: an overview. J Oncol 2010:214186

Bou DD, Lago JH, Figueiredo CR, Matsuo AL, Guadagnin RC, Soares MG, Sartorelli P (2013) Chemical composition and cytotoxicity evaluation of essential oil from leaves of Casearia sylvestris, its main compound $\alpha$-zingiberene and derivatives. Molecules 18:9477-9487

Brodeur GM (2003) Neuroblastoma: biological insights into a clinical enigma. Nat Rev Cancer 3:203-216

Brusselmans K, Vrolix R, Verhoeven G, Swinnen JV (2005) Induction of cancer cell apoptosis by flavonoids is associated with their ability to inhibit fatty acid synthase activity. J Biol Chem 280:5636-5645 
Chaudhary SC, Alam MS, Siddiqui MS, Athar M (2009) Chemopreventive effect of farnesol on DMBA/TPA-induced skin tumorigenesis: involvement of inflammation, RasERK pathway and apoptosis. Life Sci 85:196-205

Chen ZP, Schell JB, Ho CT, Chen KY (1998) Green Tea Epigallocatechin gallate shows a pronounced growth inhibitory effect on cancerous cells but not on their normal counterparts. Cancer Lett 129:173-179

Chen D, Daniel KG, Chen MS, Kuhn DJ, Landis-Piwowar KR, Dou QP (2005) Dietary flavonoids as proteasome inhibitors and apoptosis inducers in human leukemia cells. Biochem Pharmacol 69:1421-1432

Constantinou A, Mehta R, Runyan C, Rao K, Vaughan A, Moon R (1995) Flavonoids as DNA topoisomerase antagonists and poisons: structure-activity relationships. J Nat Prod 58:217-225

Davis ME, Croteau R (2000) Cyclization enzymes in the biosynthesis of monoterpenes, sesquiterpenes, and diterpenes topics in current. Top Curr Chem 209:54-92

Denyer CV, Jackson P, Loakes DMJ (1994) Isolation of antirhinoviral sesquiterpenes from ginger (Zingiber officinale). Nat Prod 57:658-662

Di Sotto A, Mazzanti G, Carbone F, Hrelia P, Maffei F (2010) Inhibition by beta-caryophyllene of ethyl methanesulfonate-induced clastogenicity in cultured human lymphocytes. Mutat Res 699:23-28

Erel O (2004) A novel automated direct measurement method for total antioxidant capacity using a new generation, more stable ABTS radical cation. Clin Biochem 37:277-285

Erel O (2005) A new automated colorimetric method for measuring total oxidant status. Clin Biochem 38:1103-1111

Hamułka J, Wawrzyniak A, Sulich A (2012) The assessment of beta-carotene, lycopene and lutein intake selected group of adults. Rocz Panstw Zakl Hig 63:179-185

Iranshahi M, Sahebkar A, Takasaki M, Konoshima T, Tokuda H (2009) Cancer chemopreventive activity of the prenylated coumarin, umbelliprenin, in vivo. Eur $\mathrm{J}$ Cancer Prev 18:412-415

Jeena K, Liju VB, Kuttan R (2011) A preliminary 13-week oral toxicity study of ginger oil in male and female Wistar rats. Int J Toxicol 30:662-670

Kazi A, Wang Z, Kumar N, Falsetti SC, Chan TH, Dou QP (2004) Structure activity relationships of synthetic analogs of (-)-epigallocatechin-3-gallate as proteasome inhibitors. Anticancer Res 24:943-954

Kilani-Jaziri S, Neffati A, Limem I, Boubaker J, Skandrani I, Ben Sghaier M, Bouhlel I, Bhouri W, Mariotte AM, Ghedira K, Dijoux-Franca MG, Chekir-Ghedira L (2009) Relationship correlation of antioxidant and antiproliferative capacity of Cyperus rotundus products towards K562. Chem Biol Interact 181:85-94

Kundu A, Saha S, Walia S, Shakil NA, Kumar J, Annapurna K (2013) Cadinene sesquiterpenes from Eupatorium adenophorum and their antifungal activity. J Environ Sci Health B 48:516-522

Kusano C, Ferrari B (2008) Total antioxidant capacity: a biomarker in biomedical and nutritional studies. J Cell Mol Biol 7:1-15

Lepley DM, Li B, Birt DF, Pelling JC (1996) The Chemopreventive flavonoid apigenin induces $\mathrm{g} 2 / \mathrm{m}$ arrest in keratinocytes. Carcinogenesis 17:2367-2375
Lewerenz V, Hanelt S, Nastevska C, El-Bahay C, Rouhrdanz E, Kahl R (2003) Antioxidants protect primary rat hepatocyte cultures against acetaminophen-induced DNA strand breaks but not against acetaminophen induced cytotoxicity. Toxicology 191:179-187

Millar JG (1998) Rapid and simple isolation of zingiberene from ginger essential oil. J Nat Prod 61:1025-1026

Mishima S, Ono Y, Araki Y, Akao Y, Nozawa Y (2005) Two related cinnamic acid derivatives from Brazilian honey bee propolis, baccharin and drupanin, induce growth inhibition in allografted sarcoma S-180 in mice. Biol Pharm Bull 28:1025-1030

Ozkan D, Yüzbaşığlu D, Unal F, Yılmaz S, Aksoy H (2009) Evaluation of the cytogenetic damage induced by the organophosphorous insecticide acephate. Cytotechnology 59:73-80

Parada-Turska J, Paduch R, Majdan M, Kandefer-Szerszeń M, Rzeski W (2007) Antiproliferative activity of parthenolide against three human cancer cell lines and human umbilical vein endothelial cells. Pharmacol Rep 59:233-237

Plaumann B, Fritsche M, Rimpler H, Brandner G, Hess RD (1996) Flavonoids activate wild-type p53. Oncogene 13:1605-1614

Ranković BR, Kosanić MM, Stanojković TP (2011) Antioxidant, antimicrobial and anticancer activity of the lichens Cladonia furcata, Lecanora atra and Lecanora muralis. BMC Complement Altern Med 20:11-97

Scalcinati G, Partow S, Siewers V, Schalk M, Daviet L, Nielsen J (2012) Combined metabolic engineering of precursor and co-factor supply to increase $\alpha$-santalene production by Saccharomyces cerevisiae. Microb Cell Fact 11:117

Singh NP, McCoy MT, Tice RR, Schneider EL (1988) A simple technique for quantitation of low levels of DNA damage in individual cells. Exp Cell Res 175:184-191

Stiller CA, Parkin DM (1992) International variations in the incidence of neuroblastoma. Int J Cancer 52:538-543

Styrczewska M, Kulma A, Kostyn K, Hasiewicz-Derkacz K, Szopa J (2012) Flax terpenoid pathway as a source of health promoting compounds. Mini Rev Med Chem 13:353-364

Svensson K, Larsson C (2003) A protein kinase Cbeta inhibitor attenuates multidrug resistance of neuroblastoma cells. BMC Cancer 26:3-10

Sylvester PW (2011) Optimization of the tetrazolium dye (MTT) colorimetric assay for cellular growth and viability. Methods Mol Biol 716:157-168

Taha MM, Abdul AB, Abdullah R, Ibrahim TA, Abdelwahab SI, Mohan S (2010) Potential chemoprevention of diethylnitrosamine-initiated and 2-acetylaminofluorene-promoted hepatocarcinogenesis by zerumbone from the rhizomes of the subtropical ginger (Zingiber zerumbet). Chem Biol Interact 86:295-305

Turkez H, Aydin E, Aslan A (2012a) Xanthoria elegans (Link) (lichen) extract counteracts DNA damage and oxidative stress of mitomycin $\mathrm{C}$ in human lymphocytes. Cytotechnology 64:679-686

Turkez H, Geyikoglu F, Mokhtar YI, Togar B (2012b) Eicosapentaenoic acid protects against 2,3,7,8-tetrachlorodibenzop-dioxin-induced hepatic toxicity in cultured rat hepatocytes. Cytotechnology 64:15-25

Turkez H, Togar B, Polat E (2012c) Olive leaf extract modulates permethrin induced genetic and oxidative damage in rats. Cytotechnology 64:459-464 
Wang Q, Wu LM, Li AY, Zhao Y, Wang NP (2001) Experimental studies of antitumor effect of artesunate on liver cancer. Zhongguo Zhong Yao Za Zhi 26:707-728

Wang YL, Li RP, Guo ML, Zhang G, Zhang N, Ma YL (2009) Bakkenolides from Petasites tricholobus and their neuroprotective effects related to antioxidant activities. Planta Med 75:230-235

Wang H, Wang Y, Liu P, Wang W, Fan Y, Zhu W (2013) Purpurides $\mathrm{B}$ and $\mathrm{C}$, two new sesquiterpene esters from the aciduric fungus Penicillium purpurogenum JS03-21. Chem Biodivers 10:1185-1192

Wassberg E, Hedborg F, Sköldenberg E, Stridsberg M, Christofferson R (1999) Inhibition of angiogenesis induces chromaffin differentiation and apoptosis in neuroblastoma. Am J Pathol 154:395-403 